\title{
A Rapid Method for Screening Transgenic Mice by PCR with Small Amounts of Blood
}

\author{
Hideaki TOJO and Masami KUBO \\ Center for Laboratory Animal Experiment, Toyama Medical \& Pharmaceutical \\ University, 2630 Sugitani, Toyama-shi, Toyama 930-01, Japan
}

(Received 12 September 1990/Accepted 23 October 1990)

\begin{abstract}
We report a rapid method for screening transgenic mice by polymerase chain reaction (PCR) with small amounts of blood. Ten to $50 \mu \mathrm{l}$ of the uncoagulated blood were collected from the transgenic mice carrying the human A $\gamma / \beta$-globin gene $(8.9 \mathrm{~kb}, 13$ and 53 copies) by puncturing the leg vein or cutting the tail end. Blood was mixed well with $200 \mu \mathrm{l}$ of the white blood cell separating-solution and was stood for 40 minutes. DNA was extracted from the blood cells in the supernatnat and was used for PCR. When 10-20 $\mu$ l of blood were applied to the cell separating-solution and the blood cells that washed out from 10-20 $\mu \mathrm{l}$ of the supernatant were used for PCR, the specific DNA band that amplified from the transgene was always detected by the electrophoresis with an agarose minigel.
\end{abstract}

\section{微量血液を用いた PCRによるトランスジェニック \\ マウスの迅速検出法}

東條英昭·久保政美

富山医科薬科大学動物実験センター

外来遺伝子を導入したトランスジェニック $(\mathrm{Tg})$ マウ スは, 今日, ヒトの遺伝病, 癌, 免疫不全症などの医学 上重要な研究課題を, 遺伝子レベルで解明してゆくため の不可欠なモデルとなってきている。

ところで, $\mathrm{Tg}$ マウスの検出は, 通常, 尾部の一部か ら抽出したDNA を元に, DNA ドットブロット法やサ ザンブロット法によって行われている $[1,4,5]$ 。しか し、これらの方法によれば, DNA の抽出から結果の判 定までには, 少なくとも $3 \sim 4$ 日を要し, しかも, 通 常, アイソトープを使用するため, 特別の設備が必要で ある。

今回, 著者らは, 微量の血液を試料として, polyme- rase chain reaction (PCR) 法を利用した, 迅速かつ 簡便な $\mathrm{Tg}$ マウスの検出法を検討したので，その結果に ついて報告する。

本実験では, 著者らが作出したヒトA $\gamma / \beta$ ーグロビン 遺伝子（13および53コピー）をへテロに保有する $\mathrm{Tg}$ マ ウス系 $[5,6]$ を供試した。

血液は, 後肢の背中足静脈を $22 \mathrm{G}$ の注射針で穿刺する 手段または尾部の先端を切断する手段によって出血さ せ、へパリン液で処理したプラスチック製チップで一定 量（10，20，30，50 $\mu$ l）を採取した。採取した血液は， そのまま，あるいは白血球を分離してから解析に供し た。白血球を分離する場合は，一定量の血夜を， $0.5 \mathrm{ml}$ 
Table 1. Optimal amounts of blood applied to the blood cell-separation and of the supernatant used for PCR to detect the transgene

\begin{tabular}{|c|c|c|c|c|c|c|c|}
\hline \multicolumn{8}{|c|}{ Supernatant volume used for PCR $(\mu \ell)^{\mathrm{a}}$} \\
\hline & \multicolumn{4}{|c|}{ Non-washed ${ }^{\mathrm{b}}$} & \multicolumn{3}{|c|}{ Washed $^{c}$} \\
\hline & 1 & 2 & 3 & 5 & 10 & 20 & 30 \\
\hline \multirow{4}{*}{ 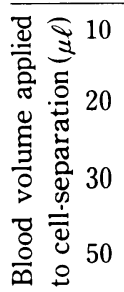 } & 0 & $\bigcirc$ & $\triangle$ & $\times$ & 0 & $\bigcirc$ & $\Delta$ \\
\hline & $\bigcirc$ & O & $\triangle$ & $x$ & O & O & $\triangle$ \\
\hline & $\bigcirc$ & O & $\triangle$ & $x$ & 0 & $x$ & $x$ \\
\hline & $\triangle$ & $\triangle$ & $\times$ & $x$ & $\triangle$ & $\times$ & $\times$ \\
\hline
\end{tabular}

a : Blood was mixed with $200 \mu \ell$ of the cell-separating solution and was stood for $40 \mathrm{~min}$. b: Cells were not washed before used for PCR. $\quad c$ : Cells were washed before used for PCR. $\bigcirc$ : DNA band was always detected. $\triangle$ : DNA band was not always detected. $\quad \times$ : DNA band was not detected.

用プラスチックチューブに入った $200 \mu 1$ の白血球分離 用溶液 (15\%ポリビニールピロリドン， $5 \%$ クェン酸ナ トリウム）と混合，筧拌したのち，室温で40分間静置し た。ついで，上澄液の $1 ， 2 ， 3$ および $5 \mu 1$ を, 下層 の赤血球を吸い込まないよら注意しそそれぞれ， $1.5 \mathrm{ml}$ 用チューブに採り, 以下に示す手順で，直接または血球 を洗浄してから DNA の抽出および PCR に供した。上澄 液をそのまま使用する場合は，採取した上澄液に，DNA 抽出夜 (1.7 $\mu \mathrm{MSDS}, 20 \mathrm{mMDTT}, 0.5 \mathrm{mg} / \mathrm{ml}$ プロテア

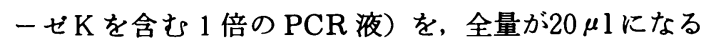
よ5に加え，䚓拌したのち， $37^{\circ} \mathrm{C} て ゙ 1$ 時間保持し，血球 細胞の溶解を行った。ついで, $85^{\circ} \mathrm{C}, 5$ 分間の処理によ

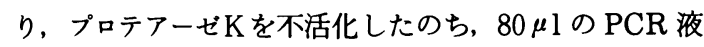
(200 $\mu \mathrm{M}$ dNTP, $1.0 \mu \mathrm{M}$ プライマー, 2.5単位 Taq I ポリメラーゼを含む1倍の PCR 液)を加え，さらに， 反応液の蒸発を防ぐため, $70 \mu 1$ のミネラルオイルを重 層し PCRを行った $[2,3]$ 。一方, 血球を洗浄してから 使用する場合には，採取した上澄液を約 $1.5 \mathrm{ml}$ の $0.85 \%$ $\mathrm{NaCl}$ 液で稀釈, 摫拌したのち， $12,000 \mathrm{rpm}, 5$ 分間遠 心して血球を回収した。ついで，血球沈渣に $20 \mu 1$ のD NA 抽出液を加光, 以後は, 前述した手順で DNA の 抽出ならびに PCR を行った。

PCR は, プログラマブルサーマルシステム（フステ ック社, PC-700) を用いて, $94^{\circ} \mathrm{C}, 55^{\circ} \mathrm{C}$ (または $65^{\circ} \mathrm{C}$ ), $72^{\circ} \mathrm{C}$ ，各 1 分つうつのサイクルを20〜30回実施した。な お，PCRに使用したプライマーは，Tg マウスに插入
されている外来遺伝子のうち，ヒト $\beta$-グロビン遗层子 内の $536 \mathrm{bp}$ を增幅する $22 \mathrm{mer}$ と $20 \mathrm{mer}$ の合成オリゴ ヌ クレオチドで，また，増幅 DNA の検出は，反応液に 1

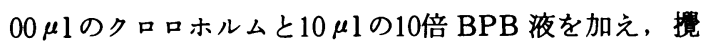
拌・遠心し, 上澄液の $15 \mu \mathrm{l}$ を, エチジウムブロマイド $(0.5 \mu \mathrm{g} / \mathrm{ml})$ を含む $1.2 \%$ アガロースミニゲルの電気泳 動（100V，30分）によって行った。

まず，血球分離後の上澄液中にどの程度の血球が含ま れているかを測定した結果, 供試血夜量が多くなるにし たがい，血球数も多く，白血球数は約 $12,000 \sim 34,000$ / $\mathrm{mm}^{3}$ で, 赤血球数は, 約 $64,000 \sim 352,000 / \mathrm{mm}^{3}$ であり, いずれの場合にも，解析に十分な白血球数が含まれてい た。つぎに, 採取した血液を、そのまま解析に使用した 結果は, 血液量 $(1 \sim 10 \mu 1)$ の違いに関俰なく, 特異 DNA バンドは全く検出されなかった。これは, 試料中 に多くの赤血球が含まれていたために, DNA の抽出や PCR か阻害されたものと考劣られる。一方，血球を分 離し，白血球を多く含む上澄液の一部を，そのまま使 用した場合と, 血球を洗浄してから使用した結果は,

Table 1 およびFig. 1に示したとおりである。

上澄液をそのまま使用した場合には，血球分離に用い た血液の量および解析に用いた上澄液の量とが共に多い 組み合わせで, DNA ハンドの検出が不確実であった り，全く検出されない結果が得られた。これは，供試し た上澄液中に残された赤血球数が多かったことや，血球 分離溶液の混入が, DNA の抽出や PCR に影䇾したも のと推察される。これに対し, 血球を洗浄してから, 解 析に供した際には, 同じく, 血球分離時の血液量と上澄 液量とが多い組み合わせで, DNA バンドの検出が困難 であった。この場合にも, 試料中の赤血球が関与したと 考えられる。しかし, その他の条件では, 常にDNA ハ ンドが検出された。なお, 本実験で使用した $\mathrm{Tg}$ マウス の解析に関する限り, 捚入遺伝子のコピー数の違いによ る結果の差異は認められなかった。

以上の結果, 微量の血液を材料として, 本実験で実施 した条件により $\mathrm{Tg}$ マウスを検出するには, 10３0 $\mu 1$ の 血液を, 白血球の分離に供し, その上澄液の $1 \sim 2 \mu \mathrm{l}$ を そのまま, または, 10〜20 $\mu$ 1 中の血球を洗浄してから 解析に供するのが最適であると判明した。

ところで，本実験に使用した $\mathrm{Tg}$ マウスは，いずれ む, 外来遺伝子が多数コピー挿入されたものである。そ こで，本方法が， 1 コピーしか遗伝子を保有していない $\mathrm{Tg}$ マウスの解析にも適用できるかどうかを調べるた め, ヒトの血夜を材料に, 同様な手法で検討した。その 結果, 血球を分離し，洗浄して用いた場合に限り，ほぽ 
$\mathrm{Tg}$ マウスで得られた結果と同様な結果が得られた。ま た，PCRに使用したプライマーについては，アニーリ ングの温度を $65^{\circ} \mathrm{C}$ に設定すれば，未精製のプライマーを 用いても，良好な結果が得られることが判明した（Fig. 2)。

最後に, 本実験では, 供試した血液の量や血球分離後 の上澄液の量を, 種々変えて検討しているものの, 血球 分離用溶液の種類やその液量や濃度については一定であ った。したがって，これらの条件をいろいると変えて検
討すれば,ささらに, より良い検出条件が得られるものと 考学る

要 約

微量の血液を試料として, PCR による迅速なトランス ジェニック $(\mathrm{Tg})$ マウスの検出法を検討した。ヒト $\mathrm{A} \gamma /$ $\beta$-グロビン遺伝子（8.9 kb, 13および53コピー）を持つ $\mathrm{Tg}$ マウスの後肢静脈を穿刺または尾部の先端を切断す

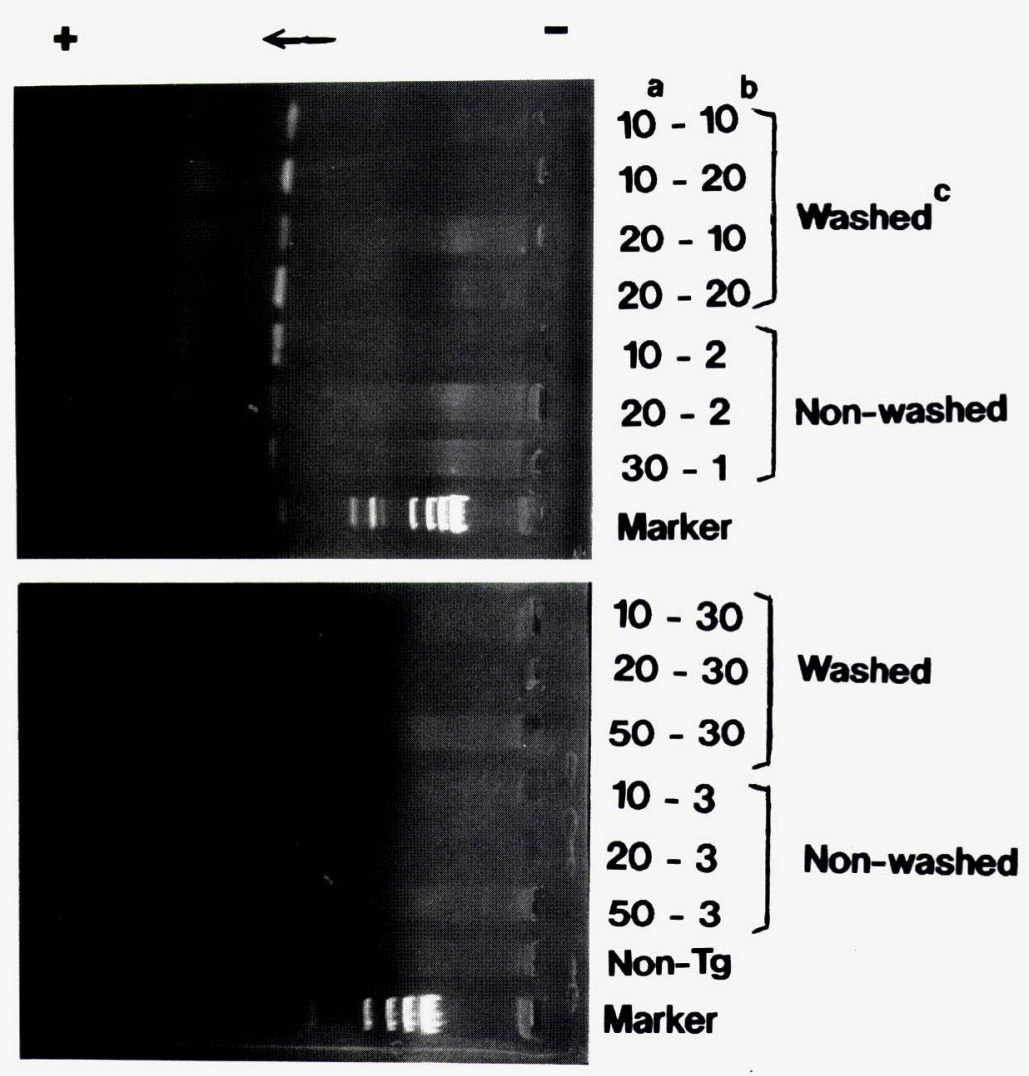

Fig. 1. Detection of the transgene by PCR method with white blood cells separated from small amounts of blood of transgenic mice. Twenty five cycles of PCR was performed with the purified primers of $20-\operatorname{mer}\left(5^{\prime}\right.$-GCTCACTCAGTGTGGCAAAG-3') and 22mer ( $5^{\prime}$-GGTTGGCCAATCTACTCCCAGG-3'), each cycle being $1 \mathrm{~min}$. at $94^{\circ} \mathrm{C}, 1 \mathrm{~min}$. at $72^{\circ} \mathrm{C}$ and $1 \mathrm{~min}$. at $55^{\circ} \mathrm{C}$. Fifteen $\mu \mathrm{l}$ of the reaction mix was run on a $1.2 \%$ agarose minigel containing 0.5 $\mu \mathrm{g} / \mathrm{ml}$ ethidium bromide at $100 \mathrm{~V}, 30 \mathrm{~min}$. and was photographed under UV light. a : Blood volume $(\mu 1)$ applied to cell separation b : Supernatant volume $(\mu 1)$ used for PCR c: Blood cells were washed or not washed before used for PCR. 


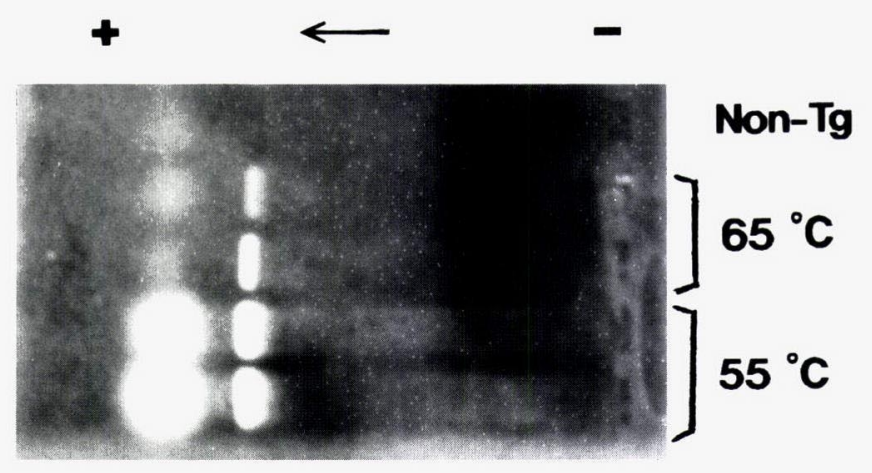

Fig. 2. PCR with the unpurified primers, in which the annealing of DNA extracted from white blood cells of transgenic mice was done at $55^{\circ} \mathrm{C}$ and at 65 ${ }^{\circ} \mathrm{C}$, respectively. Non-Tg : Sample of non-transgenic mouse a : Annealing in PCR was done at $65^{\circ} \mathrm{C} . \mathrm{b}$ : Annealing in PCR was done at $55^{\circ} \mathrm{C}$.

る手段により，凝固防止血液を $10 \sim 50 \mu$ 採取し，200 $\mu$ l の白血球分離用溶液と混合したのち，40分間静置した。 ついで，上澄液中の血球を用いて，DNAの抽出および PCR を行い, 増幅 DNA をアガロースミニゲルの電気 泳動によって検出した。その結果，血液10２0 2 1 を血 球分離に供し，その上澄液 $10 \sim 20 \mu \mathrm{l}$ 中の血球を洗浄し て解析に供した場合に, 特異 DNA バンドが常に検出さ れた。

本実験の実施にあたり，九州大学遺伝情報実験施設服巻保幸 助教授の援助を頂いた。また, 本実験は, 文部省科学研究費の 重点領域研究 (01640505) と一般研究B（63480078）により支 援された。

\section{文 献}

[1] Hogan, B., Costantini, F., and Lacy, E. (1986). Manipulating the Mouse Embryo. In A Laboratory Manual, pp 175-176.

[2] Innis, M. A., Gelfand, D. H., Sninsky, J. J., and White, T. J. (1990). PCR Protocols: A Guide to Methods and Applications, pp 13-20. Academic Press Inc.

[3] Li. H., Gyllensten, U. B., M. Cui, X., Saiki, R. K., Erlich, H. A., and Arnheim, N. (1985). Nature, 335, 414-417.

[4] Morahan, G., Brugliera, M., and Cox, K. O. (1989). Nucl Acids Res., 17, 3608.

[5] Tojo, H., Momoi, K., Fukumaki, Y., and Ogita, Z. （1987）。実験動物， 36，11-16.

[6] Tojo, H., Fukumaki, Y., and Ogita, Z. (1988). 実験動 物, 39, 347-350. 